\title{
A MCDM APPROACH FOR EVALUATION AND SELECTION OF DISTRIBUTION CHANNELS IN FMCG INDUSTRY
}

\author{
Kaveh Hatami \\ Department of Business Management, Faculty of Management, Central Tehran Branch of \\ Islamic Azad University, Tehran, Iran. \\ Bahram Kheiri* \\ Department of Business Management, Faculty of Management, Central Tehran Branch of \\ Islamic Azad University, Tehran, Iran. \\ Seyed Abbas Heydari \\ Department of Business Management, Faculty of Management, Central Tehran Branch of \\ Islamic Azad University, Tehran, Iran. \\ *Corresponding Author
}

\begin{abstract}
The purpose of this paper is to present a MCDM approach to address the problem of selecting distribution channels in marketing. In recent years, evaluating and selecting the right channels for the company has become a strategic issue in marketing, and how to select them is really a kind of multi-criteria decision making problem. In this paper, TOPSIS method is used to implement and select the appropriate distribution channel. In this method, two concepts of "ideal solution" and "similarity to ideal solution" are used and in order to measure the similarity of a design (or option) to an ideal and negative ideal solution, the distance of that design (or option) from the positive ideal and negative ideal solution is measured by giving an example. In order to collect data, we asked for cooperation of distribution experts in the industry as a participant and to weight the criteria, AHP technique was used.
\end{abstract}

Keywords: Cross-Channels, multi channels, Omni-channels, and MCDM.

Cite this Article: Kaveh Hatami, Bahram Kheiri and Seyed Abbas Heydari, A

MCDM Approach for Evaluation and Selection of Distribution Channels in FMCG

Industry, International Journal of Management 11(12), 2020, pp. 404-414.

http://iaeme.com/Home/issue/IJM?Volume=11\&Issue $=12$ 


\section{INTRODUCTION}

In the contemporary world, businesses usually do not sell their products directly to end users, and between them and end users, many independent organizations may be involved in delivering products to consumers and making them available. Organizations that specialize in this area are called marketing intermediaries (Dickmen et al., 2008). One of the importance of intermediaries is the Baligh-Richardtz (1964) effect that the integration of an intermediary in the distribution channel can reduce the number of necessary contacts between the players of this channel. Distribution channel development is a key element in the marketing strategies of many manufacturers, and thanks to the Internet and technology development, manufacturers are able to sell their products directly, through intermediaries and combinations of both to end users without the need for Brick and mortar stores (Zentes et al., 2017, p. 125). As a result, one of the most important developments in recent decades has been the transfer of power among members of the distribution channel. Global competition has forced organizations to optimize not only at the organization level, but also at the level of their supply chain and distribution channels (Daneshvar and Gholamrezanezhad, 2017).

\section{BACKGROUND}

In the marketing literature, several models of distribution channels have been considered (Dickmen et al., 2008). But the main purpose of all is to distribute or place the product in order to bring it closer to potential customers or the target market (Trihatmoko and Mulyani, 2018). In the meantime, due to the wide changes in consumer buying behavior, distribution strategies (which will be used as alternatives) have also undergone several changes, which we will briefly explain in the following (Lokviarman et al., 2018).

\subsection{Cross-channel distribution}

Cross-channel distribution is when retailers use multiple channels to sell their goods in parallel (Zentes et al., 2017, p. 95). Cross-channel retailing indicates a higher degree of channel integration, providing unique shopping opportunities for customers across all of a store's retail channels. Customers can change retail channels at any stage of the buying process (Levy et al., 2014). For example, they can choose a product in the store but order it online. Retailers can take advantage of the unique benefits of different distributions by combining alternative channels to form a cross-channel distribution system and thus create more value for the customer (Klein et al., 2014, p. 20).

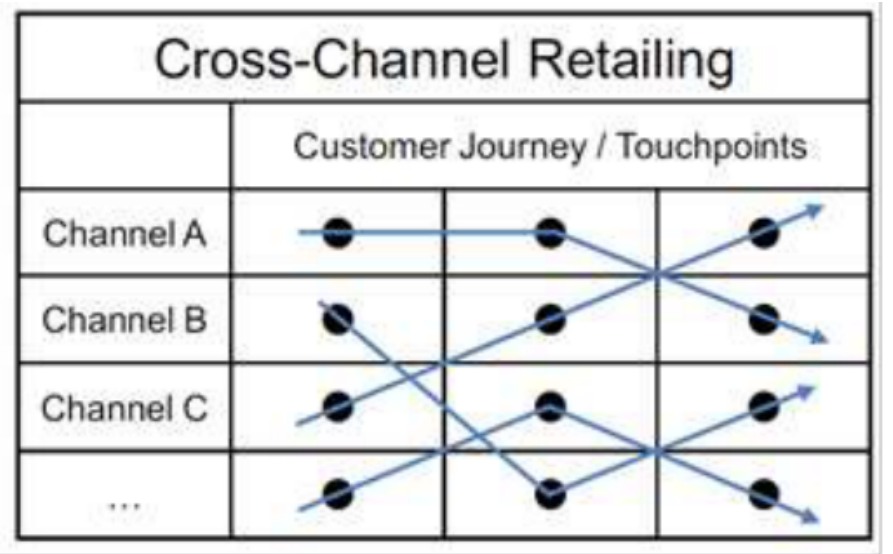

Figure 1. Cross-channel distribution (Adapted from Zentez et al., 2017, p. 97) 


\subsection{Multi-channel distribution}

In multi-channel distribution, a retailer uses multiple retail channels simultaneously to sell similar goods. Therefore, the channels overlap. Customers can select and purchase the goods they need through various retail channels (Klein et al., 2014). The evolution of new devices that enable Internet access in innovative ways, by combining different types of online shopping devices in multi-channel e-commerce systems, has created a new form of multi-channel retail systems (Lokviarman et al. Others, 2018). In such a multi-channel e-commerce environment, consumers make their purchases through multiple electronic channels (e.g., mobile devices) and electronic platforms (e.g., mobile shopping apps). Thus there is no physical or traditional channel (Zentez et al., 2017, p. 99).

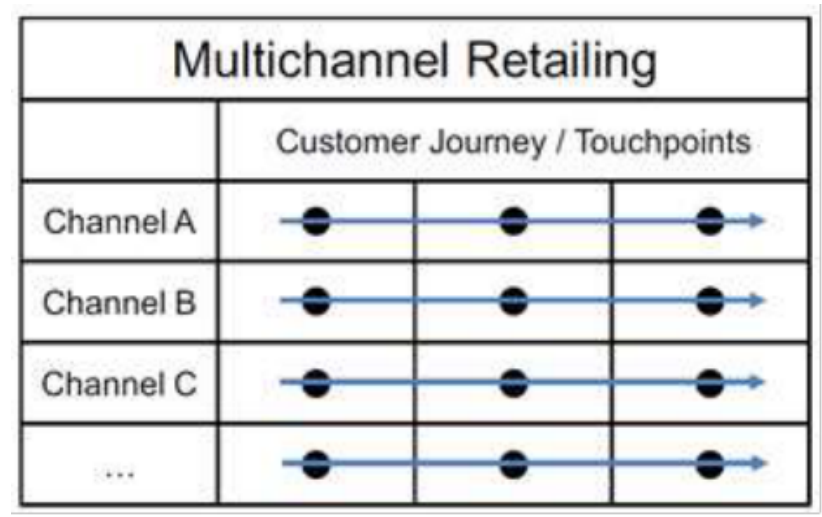

Figure 2. Multi-Channel Distribution (Adapted from Zentez et al., 2017, p. 97)

\subsection{Omni-Channel Distribution}

The term "Omni-Channel distribution" refers to a strategy in which customers have the same experience across all of a retailer's different channels and cross-channel distribution processes. This is possible by the fact that multiple interactions between consumers can be structured so that consumers can easily communicate with a retailer through their preferred channels (Webster, 2010). Omni-Channel distribution, through comprehensive cooperation, enables functions that let customers to research the purchase, purchase, communication, participation and consumption of the brand through physical, online, mobile, social networking channels, etc. (Palmatiuer et al., 2019, p. 14). In Omni-Channel distribution systems, CRM faces the challenge of having to collect and integrate information about the buying behavior of specific customers through different channels to be able to provide a comprehensive picture. Thus, in Omni-Channel distribution systems, various sources of customer information can be used to gain consumer insight (Zentez et al., 2017, p. 362) and to track their behavior (Lane, 2014, p. 299). 


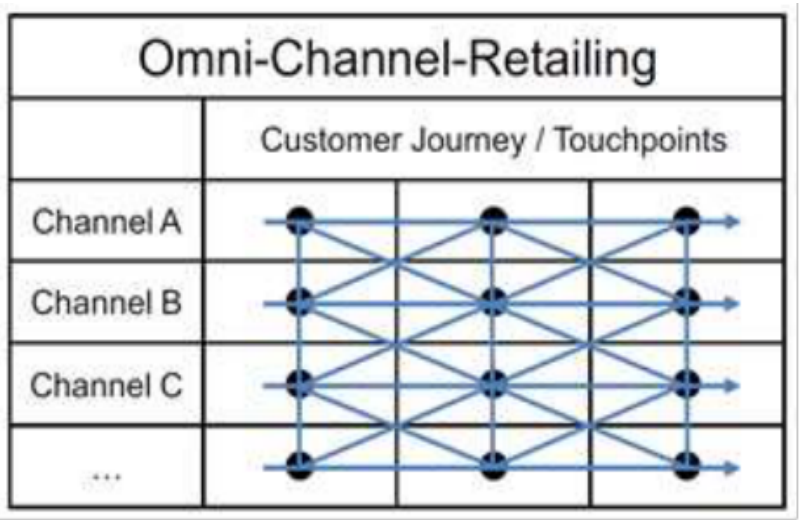

Figure 3. Omni-Channel Distribution (Adapted from Zentez et al., 2017, p. 97)

In order to examine the available alternatives for selecting a distribution channel by the company, it is inevitable to examine the characteristics of each. These features are often complex and not easily quantifiable and are therefore fuzzy.

\subsection{Convenience}

It refers to the attitude of buyers (Holbrook, 1986) towards purchasing as a way to maximize their individual economic efficiency and specifically examines ways to minimize their search and transaction costs. This feature emphasizes the usefulness of the purchase value as a fundamental, rational, intentional and efficient activity. Therefore, shoppers looking for this convenience try to minimize their search costs as much as possible and spend their time or energy on other activities (Kang, 2012).

\subsection{Inventory Management}

Inventory management is the amount of inventory required for each product stored in warehouses (Zentez et al., 2017, p. 400). The traditional warehouse system is very expensive. Inventory is expensive and can be obsolete. In addition, many operations occur in the physical circulation of goods, including the entry, movement and exit of goods. In order to reduce inventory and improve the speed of goods circulation, inventory management is inevitable (Coyl et al., 2013, p. 20). The main goal of inventory management is to reduce material shortages in warehouses with the centrality of its forecasting through integrated inventory management and its availability for all channels, the availability of their information and special inventory management for each channel (Bering Point, 2015 P. 41).

\subsection{Transfer cost}

Any operation performed in the distribution channel leads to the creation of valuable service outputs as well as costs (Palmatiuer et al., 2019, p. 46). To compare the costs and profitability of different marketing channels, it is necessary to identify marketing activities and measure the costs associated with these activities, including packaging and storage, transportation, sales, and operating costs (Hardesty and Leff, 2010).

\subsection{Order Management}

Vendors need an advanced order management system to synchronize inventory in distribution centers to find the shortest route to quickly receive products and deliver them to consumers while avoiding warehousing (Palmatiuer et al., 2019, p. 355). However, there are limitations that often create problems in order management in organizations. For example, stockpiling products in order to be flexible in ordering is costly. Moreover, many of these products may 
remain in stock and never be sold, so all resources (raw materials, work forces, equipment) are wasted (Manzouri et al., 2011).

\subsection{Return Management}

In recent years, distribution channel players have become increasingly involved in reverse logistics operations. This means increasing the return of products and referring them for recycling or reuse (Fernie and Sparks, 2014, p. 7). This is more evident in online channels (Zentes et al., 2017, p. 408). Product return management is a vital issue in the distribution channel management process that requires effective implementation and planning. Effective implementation of this process enables managers to identify productive opportunities. This process requires more interaction between channel members (Fernie and Sparks, 2014, p. 10).

\subsection{Conflict Management}

Conflict in distribution channels is not a new phenomenon and is well known in the consumer goods industry. Moreover, the main challenge for manufacturers is conflict management in distribution systems and their members (Zentes et al., 2017, p. 125). Many retailers believe that the integration of the online channel as a complementary distribution channel in the traditional distribution system does not create new sales and attracts sales from existing channels and causes conflict (Yumurtaci et al., 2016).

\subsection{Sales Management}

Identifying the people who are in charge of channel management is of particular importance, especially during the development of electronic channels. Because it has major effects on hiring, selecting, training and evaluating the performance of sales managers (Mehta et al., 2013). Sales managers in consumer product companies are significantly involved in channel strategy formulation, marketing channel design, motivating channel members, and managing conflict with their peers (Carrefour, 2015). For this reason, sales management, which mainly deals with sales force management, planning and idea generation for sales, is very important in the distribution channel (Zentes et al., 2017, p. 106).

\subsection{Delivery Time}

The possibility that in a store there is not only the ability to search but also the ability to buy, without the need to spend a lot of time for delivery, is a necessity to make shopping easier for customers (Kingfisher, 2015). Consumers are different in the threshold of patience and acceptance of the lack of inventory in the warehouse, and even the same consumers in different conditions of purchase express different reactions. Increasing demand for products during the distribution channel means that the product is always in stock and therefore imposes additional costs on channel members (Palmatiuer et al., 2019).

\section{METHODOLOGY}

TOPSIS sees a multi criteria problem with $\mathrm{m}$ alternatives as a geometric system with points $\mathrm{m}$ in the $\mathrm{n}$ dimension spaces. The method is based on the concept that the alternative should have the shortest distance from the positive-ideal solution and the longest distance from the negative-ideal solution. TOPSIS defines an indicator called similarity with a positive-ideal solution and avoidance of a negative-ideal solution. It then selects the alternative method with the maximum resemblance to the positive-ideal solution (Hwang and Yoon, 1981). If an alternative look like an ideal solution, it has a higher degree. The ideal solution is one that is practically the best in every aspect that does not exist, and we try to approximate it. Basically, to measure the similarity of a design (or alternative) with a positive ideal and negative ideal level, we consider the distance of that design from the positive ideal and negative-ideal solution (Rouyendegh, 2015). According to the AHP method, the idea of creating weight tries to evaluate the weight without any relevant intervention of decision makers. The importance 
of these metrics is that they convey the direct function of information to all decision-making units (DMUs) (Rouyendegh, 2017). Among the advantages of this method are measuring the consistency of decision makers' judgments, creating pairwise comparisons in choosing the optimal solution and option, being able to consider criteria and sub-criteria in evaluating options, and creating the ability to achieve the best alternative through pairwise comparisons. The first step in identifying pairwise comparisons and constructing a decision matrix can be to create possible DMUs and calculate criteria. Assume that there are $\mathrm{m}$ alternatives, $\mathrm{n}$ evaluation criteria, and $\mathrm{K}$ the number of decision makers in a decision problem. A framework model for calculating pairwise comparisons for each hierarchical level is calculated by optimizing pairwise relationships evaluated using AHP and introduced by Thomas Saaty (1980).

Table 1. Fundamental scales

\begin{tabular}{|l|l|}
\hline \multicolumn{1}{|c|}{ Importance Intensity } & \multicolumn{1}{|c|}{ Definition } \\
\hline 1 & Equal Significance \\
\hline 3 & Moderate Significance of One \\
\hline 5 & Strong Significance of One \\
\hline 7 & Very Strong Significance of \\
\hline 9 & Extreme Significance of One \\
\hline
\end{tabular}

An MCDM problem in which A1, A2 ... Am have possible options for the decision maker to choose from, and $\mathrm{C} 1, \mathrm{C} 2 \ldots \mathrm{Cn}$ are the criteria by which each alternative function is measured. Express the following matrix:

\begin{tabular}{l|llllll} 
& $\mathbf{C}_{\mathbf{1}}$ & $\mathbf{C}_{\mathbf{2}}$ & $\cdot$ & $\cdot$ & $\cdot$ & $\mathbf{C}_{\mathbf{n}}$ \\
\hline $\mathbf{D}=$ & $\mathrm{X}_{11}$ & $\mathrm{X}_{12}$ & $\cdot$ & $\cdot$ & $\cdot$ & $\mathrm{X}_{1 \mathrm{n}}$ \\
$\mathbf{A}_{\mathbf{2}}$ & $\mathrm{X}_{21}$ & $\mathrm{X}_{22}$ & $\cdot$ & $\cdot$ & $\cdot$ & $\mathrm{X}_{2 \mathrm{n}}$ \\
$\cdot$ & $\cdot$ & $\cdot$ & $\cdot$ & $\cdot$ & $\cdot$ & $\cdot$ \\
$\cdot$ & $\cdot$ & $\cdot$ & $\cdot$ & $\cdot$ & $\cdot$ & $\cdot$ \\
$\cdot$ & $\cdot$ & $\cdot$ & $\cdot$ & $\cdot$ & $\cdot$ & $\cdot$ \\
$\mathbf{A}_{\mathbf{m}}$ & $\mathrm{X}_{\mathrm{m} 1}$ & $\mathrm{X}_{\mathrm{m} 2}$ & $\cdot$ & $\cdot$ & $\cdot$ & $\mathrm{X}_{\mathrm{mn}}$
\end{tabular}

$\mathrm{W}=\left[\begin{array}{llll}\mathrm{W}_{1} & \mathrm{~W}_{2} & \ldots & \ldots\end{array}\right.$

Formula (1)

In the second step, the normalized decision matrix (NDM) and the R matrix are executed as follows:

$$
r_{i j}=\frac{x_{i j}}{\sqrt{\sum_{k=1}^{m} x_{k j}^{2}}}
$$

Formula (2) 
Kaveh Hatami, Bahram Kheiri and Seyed Abbas Heydari

$$
R_{i j}=\left[\begin{array}{cccc}
r_{11} & r_{12} & \cdot & r_{1 n} \\
r_{21} & r_{22} & \cdot & r_{2 n} \\
\cdot & \cdot & \cdot & \cdot \\
r_{m 1} & r_{m 2} & \cdot & r_{m n}
\end{array}\right]
$$

\section{Formula (3)}

In the third step, the weighted normal decision matrix (WNDM) is calculated as follows.

$$
v_{i j}=\left[\begin{array}{cccc}
w_{1} r_{11} & w_{2} r_{12} & \ldots & w_{n} r_{1 n} \\
w_{1} r_{21} & w_{2} r_{22} & \ldots & w_{n} r_{2 n} \\
\cdot & \cdot & \ldots & . \\
w_{1} r_{m 1} & w_{2} r_{m 2} & \ldots & w_{n} r_{m n}
\end{array}\right]
$$

\section{Formula (4)}

In the fourth step, the type of criteria must be specified. Criteria are either positive or negative. Positive criteria are criteria whose increase improves the system, and the positive ideal solution is equal to the largest cell column and the negative ideal is equal to the smallest cell. For negative criteria, this trend applies in reverse.

$$
\begin{aligned}
& A^{+}=\left\{\left(\max _{i} v_{i j} \mid j \in J\right),\left(\min _{i j} v_{i} j \in J^{\prime}\right)\right\} \\
& \left.A^{-}=\left\{\max _{i} v_{i j} \mid j \in J^{\prime}\right),\left(\min _{i j} v_{i} \mid j \in J^{\prime}\right)\right\}
\end{aligned}
$$

\section{Formula (5)}

In the fifth step, based on the following equation, the distance between each option and its positive and negative ideals is calculated.

$$
\begin{aligned}
& d_{i}^{+}=\sqrt{\sum_{j=1}^{n}\left(v_{i j}-v_{j}^{+}\right)^{2}} \\
& d_{i}^{-}=\sqrt{\sum_{j=1}^{n}\left(v_{i j}-v_{j}^{-}\right)^{2}}
\end{aligned}
$$

\section{Formula (6)}


In the final step, the similarity index and the ranking of alternatives are calculated. The similarity index indicates the score of each option, and the closer this index is to the number one, the superiority of that option.

$$
c l_{i}^{+}=\frac{d_{i}^{-}}{d_{i}^{-}+d_{i}^{+}}
$$

\section{Formula (7)}

This study has provided a comprehensive system for selecting the appropriate distribution channel in the Iranian FMCG industry based on multi-criteria decision making. Having usable and reliable data is the basis for deciding on the most optimal decision option. For this purpose, the opinions of experts from the relevant departments were reviewed and data were collected and analyzed through surveys. The main criteria in selecting the distribution channel are order management, inventory management, return management, sales management, transfer cost, delivery time, convenience and conflict management, and decision makers choose from cross-channel distribution, multi-channel distribution and Omni-Channel distribution.

\section{CALCUlations}

The TOPSIS method can be implemented using its algorithm, which is discussed in Table 2.

Table 2. The main criteria of the distribution channel

\begin{tabular}{|l|l|l|l|l|l|l|l|l|}
\hline & $\begin{array}{l}\text { Order } \\
\text { management }\end{array}$ & $\begin{array}{l}\text { Inventory } \\
\text { management }\end{array}$ & $\begin{array}{l}\text { Returned } \\
\text { Goods }\end{array}$ & $\begin{array}{l}\text { Sales } \\
\text { management }\end{array}$ & $\begin{array}{l}\text { Transfer } \\
\text { costs }\end{array}$ & $\begin{array}{l}\text { Delivery } \\
\text { Time }\end{array}$ & Convenience & $\begin{array}{l}\text { Conflict } \\
\text { Management }\end{array}$ \\
\hline Cross-channel & 7 & 5 & 5 & 7 & 5 & 3 & 1 & 5 \\
\hline Multi-channel & 5 & 3 & 1 & 5 & 7 & 5 & 3 & 3 \\
\hline Omni-channel & 9 & 7 & 3 & 9 & 7 & 7 & 5 & 7 \\
\hline Normalization & $\begin{array}{l}\text { Order } \\
\text { management }\end{array}$ & $\begin{array}{l}\text { Inventory } \\
\text { management }\end{array}$ & $\begin{array}{l}\text { Returned } \\
\text { Goods }\end{array}$ & $\begin{array}{l}\text { Sales } \\
\text { management }\end{array}$ & $\begin{array}{l}\text { Transfer } \\
\text { costs }\end{array}$ & $\begin{array}{l}\text { Delivery } \\
\text { Time }\end{array}$ & Convenience & $\begin{array}{l}\text { Conflict } \\
\text { Management }\end{array}$ \\
\hline Cross-channel & 0.56 & 0.54 & 0.84 & 0.56 & 0.40 & 0.33 & 0.17 & 0.54 \\
\hline Multi-channel & 0.40 & 0.33 & 0.17 & 0.40 & 0.56 & 0.54 & 0.50 & 0.33 \\
\hline Omni-channel & 0.72 & 0.76 & 0.50 & 0.72 & 0.72 & 0.76 & 0.84 & 0.76 \\
\hline
\end{tabular}

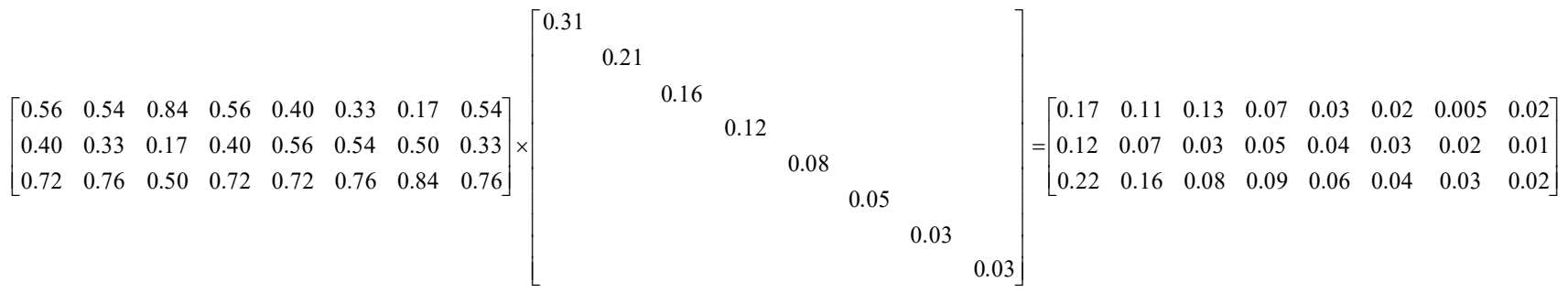

$$
\begin{aligned}
& A^{+}=\left[\begin{array}{llllllll}
0.22 & 0.07 & 0.03 & 0.09 & 0.03 & 0.02 & 0.03 & 0.02
\end{array}\right] \\
& A^{-}=\left[\begin{array}{llllllll}
0.12 & 0.16 & 0.13 & 0.05 & 0.06 & 0.04 & 0.01 & 0.01
\end{array}\right] \\
& d_{1}^{+}=0.129, d_{2}^{+}=0.109, d_{3}^{+}=0.110 \\
& d_{1}^{-}=0.078, d_{2}^{-}=0.142, d_{3}^{-}=0.122
\end{aligned}
$$




$$
c_{1}=0.377, c_{2}=0.565, c_{3}=0.526
$$

\section{Calculations (1)}

After examining the Euclidean distance of each alternative from its positive and negative ideals, the similarity index was calculated and the result was presented in Table 3.

\begin{tabular}{|l|l|l|}
\hline \multicolumn{1}{|c|}{ Distribution Channel } & \multicolumn{1}{c|}{ Similarity Index } & \multicolumn{1}{c|}{ Rank } \\
\hline Cross-channel & 0.377 & 3 \\
\hline Multi-channel & 0.565 & 1 \\
\hline Omni-channel & 0.526 & 2 \\
\hline
\end{tabular}

Table 3. TOPSIS model output

According to the results, cross-channel distribution is in the third place, while multi-channel distribution is in the first place and Omni-Channel distribution is in the second place in the distribution of FMCG products. As can be seen in Table 3, multi-channel distribution as the most significant type of distribution channel from the perspective of selected experts and Omni-Channel distribution and cross-channel distribution were also in the next priorities, respectively.

\section{RESULTS}

The main purpose of this study is to identify the data related to the selection of the best distribution channel appropriate to the type and nature of the product. For this purpose, multicriteria decisions are studied and solved by TOPSIS model and it seems that the results will have a significant impact on the industry under study. Because the selection of the main distribution channel and the creation of a reliable structure close to its members in competitive and critical conditions is very important today, several decision makers from organization departments are involved in the selection process. For this reason, each of the decision makers from their own point of view prioritizes the criteria, and sometimes the decision making is vicious and time consuming. Using MCDM and TOPSIS technique, especially in times when data are unreliable, more accurate results can be achieved easily and with less time. It seems that by using this method, other decision-making situations in the organization can be managed. It is also possible to repeat this research and examine the results, depending on the type and nature of the goods or services.

\section{REFERENCES}

[1] Baligh, H., \& Richartz, L. (1964). An analysis of vertical market structure. Management Science, 10(4), 667-689.

[2] Carrefour (2015). Full year report. http://www.carrefour.com/finances/releases?link=1785. Accessed March 12, 2015.

[3] C.L. Hwang and K.Yoon,(1981). Multiple Attribute Decision Making - Methods and Applications: A State of the Art Survey, Springer- Verlag.

[4] Coyle, J. J., Langley, J., Novack, R. A., \& Gibson, B. J. (2013). Supply chain management: A logistics perspective (9th edn.). Mason, OH: South-Western/Thomson Learning. 
[5] Dikmen, F. Cengiz; \& Say, T. (2008). A MCDM Approach for Middlemen evaluation and Selection in Marketing, Serbian Journal of Management, 3 (1) (2008) 5 - 15.

[6] Fernie, J., \& Sparks, L. (2014). Retail logistics: Changes and challenges. In J. Fernie \& L. Sparks (Eds.), Logistics and retail management: Emerging issues and new challenges in the retail supply chain (4th ed., pp. 1-33). London et al.: Kogan Page.

[7] Hardesty, Shermain D.; \& Leff, Penny. (2010). Determining marketing costs and returns in alternative marketing channels, Renewable Agriculture and Food Systems, 25(1); 24-34.

[8] Holbrook, M.B. (1986). Emotion in the consumption experience: toward a new model of the human consumer. In R.A. Peterson, et al., (Eds.), the role of affect in consumer behavior: Emerging theories and applications (pp. 17-52). Lexington, MA: Heath.

[9] Kang, Bomi. (2012). The impact of channel knowledge on shopping orientations in consumer buying behavior, Anatolia - An International Journal of Tourism and Hospitality Research, Vol. 22, No. 1,120-124.

[10] Kingfisher Group. (2015). Annual report. http://www.kingfisher.com/files/reports/annual_report_2015/files/pdf/annual_report_2015.pdf. Accessed June 25, 2015.

[11] Levy, M., Weitz, B., \& Grewal, D. (2014). Retailing management (9th edn.). Boston et al.: McGraw-Hill Education.

[12] Manzouri, Malihe.; Ab Rahman, Mohd Nizam.; \& Arshad, Haslina. (2011). Order Management in Supply Chain: A Case Study in Automotive Companies, American J. of Engineering and Applied Sciences, 4 (3): 372-379.

[13] Mehta, Rajiv; Rosenbloom, Bert; \& Anderson, Rolph. (2013). Roles of the sales manager in channel management: Impact of organizational variables, Journal of Personal Selling and Sales Management, 20(2):81-88.

[14] Palmatiuer, Robert W.; Sivadas, Eugene; Stern, Louis W.; El-Ansary, Adel I. (2019). "Marketing Channel Strategy: An omni-channel Approach," Routledge Publications, 9th edition.

[15] Rouyendegh, B. D. (2015). Developing an integrated ANP and intuitionistic fuzzy TOPSIS model for supplier selection. Journal of Testing \& Evaluation, 43(3), 664-672.

[16] Rouyendegh, B. D; \& Gholamrezanezhad, F. (2017). A MCDM approach for supplier selection process: A pilot study from Iran, Marketing and Branding Research 4(2017) 129134.

[17] Saaty, T. L. (1980). The analytical hierarchy process. New York: McGraw Hill.

[18] Schramm-Klein, H. \& Wagner, G. (2014). Multichannel-E-Commerce -Neue Absatzwegeim Online-Handel, in: Crockford, G., Ritschel, F., \& Schmieder, U.-M. (Ed.): Handel in Theorie und Praxis, Springer-Gabler, Berlin, pp. 467-492.

[19] Trihatmoko, R. Agus.; \& Mulyani, Roch. (2018). Distribution strategy for new product marketing success: fast moving consumer goods business, Management and Human Resource Research Journal, Vol.7, No.12, p 19-32. 
[20] Yumurtaci, I.O.; Ersoy, P.; \& Börühan, G. (2016). Marketing channel strategy and the effect of cannibalization on retailing: A conceptual overview from marketing and supply chain perspective, Yönetim ve Ekonomi Araştırmaları Dergisi- Vol: 14 No.2.

[21] Zentes, Joachim; Morschett, Dirk; \& Schramm-Klein, Hanna. (2017). Strategic Retail Management, Springer Gabler, 3rd edition. 